\begin{tabular}{|c|c|c|}
\hline BENTHAM OPEN & The Open Civil Engineering Journal & $\begin{array}{l}\text { The Open } \\
\text { Crill Engine. }\end{array}$ \\
\hline CrossMark & Content list available at: www.benthamopen.com/TOCIEJ/ & स्रात्व \\
\hline & DOI: $10.2174 / 1874149501610010807$ & \\
\hline
\end{tabular}

RESEARCH ARTICLE

\title{
Compressive Behavior of Recycled Mortar After Exposure to High Temperatures
}

\author{
Jiong-Feng Liang ${ }^{*}$ a,b, Ze-Ping Yang ${ }^{\mathrm{b}}$, Ping-Hua $\mathrm{Yi}^{\mathrm{b}}$ and Jian-Bao Wang ${ }^{\mathrm{b}}$ \\ ${ }^{a}$ Jiangxi Engineering Research Center of Process and Equipment for New Energy, East China Institute of Technology, \\ Nanchang 330013, China \\ ${ }^{b}$ Faculty of Civil and Architecture Engineering, East China Institute of Technology, Nanchang, 330013, China
}

Received: April 18, 2016

Revised: September 18, 2016

Accepted: September 20, 2016

\begin{abstract}
The possibility of using fine recycled concrete aggregate as a substitute for natural sand are relatively limited. In order to promote it for engineering application, this paper reports the effect of elevated temperatures from room temperature to $600^{\circ} \mathrm{C}$ on the compressive behavior of mortars containing recycled fine concrete aggregate was investigated. It is found that no obvious relation between the color change and the recycled mortars replacement percentage.And the mass loss of recycled mortars is larger than that of normal mortars. The compressive strength of recycled mortars declines significantly as the temperature rises. The elastic modulus of recycled mortars decreased with the increase in temperature, and the decrease is much quicker than the decrease in compressive strength.
\end{abstract}

Keywords: Compressive behavior, Elastic modulus, Elevated temperature, Recycled fine concrete aggregate, Recycled mortars.

\section{INTRODUCTION}

In recent years, considerable effort have been directed towards investigating the possibility of using coarse recycled concrete aggregate (RCA) as a substitute for natural coarse aggregate (NCA) in concrete construction. This had led to a deeper understanding of the ways and means of processing demolished concrete, mixture design of RAC, its physical and mechanical properties for an exhaustive treatment of various aspects of this material [1]. But the possibility of using fine recycled concrete aggregate as a substitute for natural sand is relatively limited.

The use of recycled fine concrete aggregate as sand in concrete had been studied by several other researchers [2 - 4]. Their works revealed that recycled fine aggregate lowers the quality of the concrete in mechanical strength and durability. Buyle-Bodin et al. [5] found that recycled fine aggregate increased porosity and permeability of the concrete.

Zhao et al. [6] studied the properties of mortars containing fine recycled concrete aggregates, including fresh properties, mechanical properties and interfacial transition zone (ITZ) microstructure.

Studies on properties of masonry mortars manufactured with fine recycled concrete aggregates revealed that a replacement ratio of fine recycled concrete aggregate up to $40 \%$ was a viable alternative for producing environmentally friendly masonry mortar [7].

In this study, the effect of elevated temperature on the compressive behavior of mortars containing recycled fine concrete aggregate was investigated.

\footnotetext{
* Address correspondence to this author at the Jiangxi Engineering Research Center of Process and Equipment for New Energy, East China Institute of Technology, No. 418, Guanglan Road, Nanchang City, Jiangxi Province, China; Tel: +86-18079128089; Fax: +86-791-83879022; E-mails: jiongfeng108@126.com, jiongfeng108@163.com
} 


\section{EXPERIMENTAL DETAIL}

\subsection{Materials and Mix Proportions}

Two types of fine aggregate were used in this research. One of the fine aggregate was natural river sand, which met Chinese Standard "GBT14684-2011" [8].The second type was recycled fine concrete aggregate (FCA) obtained from crushing waste concretes from curbs and sidewalks in Nanchang, PR China. The physical properties of fine aggregates are shown in Table 1. Fig. (1) presents the size grading of the aggregates. Ordinary Portland cement with a $28 \mathrm{~d}$ compressive strength of $32.5 \mathrm{Mpa}$ was used in this investigation, which was compatible with Chinese Standard "GB175-2007" [9]. The chemical composition of ordinary Portland cement is stated in Table 2.

Table 1. Physical properties of fine aggregates.

\begin{tabular}{|c|c|c|c|c|c|c|}
\hline Type of fine aggregates & $\begin{array}{l}\text { Fineness } \\
\text { modulus }\end{array}$ & $\begin{array}{c}\text { Bulk density } \\
\left(\mathrm{kg} / \mathrm{m}^{3}\right)\end{array}$ & \begin{tabular}{|c|}
$\begin{array}{c}\text { Apparent density } \\
\left(\mathrm{kg} / \mathrm{m}^{3}\right)\end{array}$ \\
\end{tabular} & Silt content $(\%)$ & $\begin{array}{c}\text { Water absorption } \\
(\%)\end{array}$ & Crushing value $(\%)$ \\
\hline River sand & 2.6 & 1460 & 2610 & 1.56 & 4.3 & 11.1 \\
\hline Recycled sand & 3.2 & 1280 & 2480 & 2.5 & 6.6 & 18.7 \\
\hline
\end{tabular}

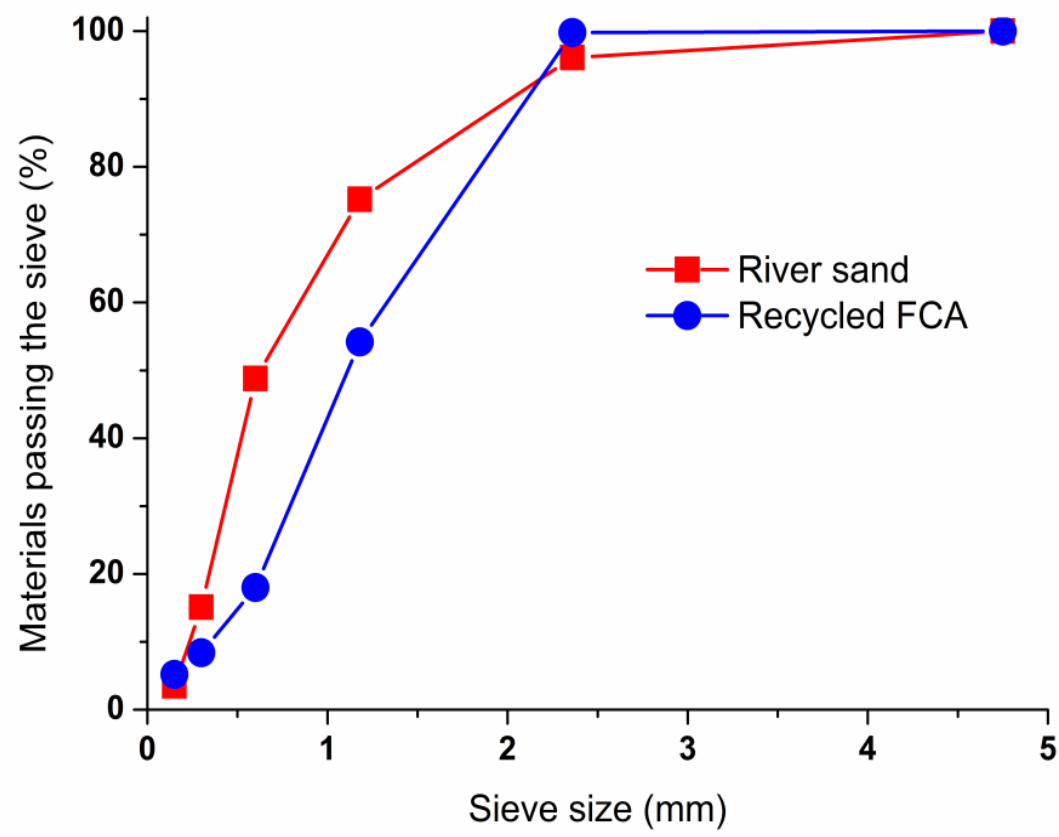

Fig. (1). Particle size distribution of fine aggregates.

Table 2. Chemical composition of ordinary Portland cement (\%).

\begin{tabular}{|c|c|c|c|c|c|c|c|}
\hline Lime (Cao) & Silica $\left(\mathrm{SiO}_{2}\right)$ & Alumina $\left(\mathrm{Al}_{2} \mathrm{O}_{3}\right)$ & Iron oxide $\left(\mathrm{Fe}_{2} \mathrm{O}_{3}\right)$ & Sodium oxide $\left(\mathrm{Na}_{2} \mathrm{O}\right)$ & Magnesium oxide (MgO) & \begin{tabular}{|c|}
$\begin{array}{c}\text { Potassium } \\
\text { oxide }\left(\mathrm{K}_{2} \mathrm{O}\right)\end{array}$ \\
\end{tabular} & $\begin{array}{c}\text { Sulfur } \\
\text { trioxide }\left(\mathrm{SO}_{3}\right)\end{array}$ \\
\hline 56.52 & 23.18 & 7.06 & 3.32 & 4.25 & 2.05 & 0.89 & 1.98 \\
\hline
\end{tabular}

Three mortar mixtures consisting of $0 \%, 50 \%, 100 \%$ recycled fine concrete aggregate as a partial replacement for sand were prepared. These mixtures were used to investigate the effect of recycled aggregate on the mechanical properties of mortar exposed to elevated temperatures. Details of the mortars mixtures are given in Table 3. Due to high water absorption of recycled fine concrete aggregate, the water of the mortars mixtures included mixing water and added water. This may make the proportion w/c high.

Table 3. Mix proportions of mortars $\left(\mathrm{kg} / \mathrm{m}^{3}\right)$.

\begin{tabular}{|c|c|c|c|c|c|c|}
\hline Mix & Recycled aggregate content (\%) & Cement & Recycled fine aggregate & Natural sand & Mixing water & Added water \\
\hline NM & 0 & 240 & - & 1500 & 320 & 0 \\
\hline RM50 & 50 & 240 & 730 & 730 & 320 & 35 \\
\hline RM100 & 100 & 240 & 1430 & - & 320 & 70 \\
\hline
\end{tabular}




\subsection{Test Methods}

Prism mortar specimens $(70.7 \times 70.7 \times 212 \mathrm{~mm})$ were cast for each mixture and prepared to determine the effect of different temperatures on mass loss, compressive strength and modulus of elasticity. After casting, the mortar specimens were kept in their moulds for $24 \mathrm{~h}$ at room temperature $\left(20 \pm 2^{\circ} \mathrm{C}\right)$. After $24 \mathrm{~h}$, the specimens were demoulded and cured in a fog room $\left(20 \pm 2^{\circ} \mathrm{C}, 95 \%\right.$ relative humidity) for 28 days, and then dried at room temperature for 7 days. The mortar specimens were heated in an electric furnace to temperatures of $200,400,600^{\circ} \mathrm{C}$. In order to ensue that the temperatures in the center of the mortar specimens also reached the target temperatures, the temperature was maintained at $200,400,600^{\circ} \mathrm{C}$ for $3 \mathrm{~h}$ respectively. After completion of the heating regimes, specimens were removed from the furnace and the mass losses of specimens for each temperature were measured. The heated mortar specimens were then cooled to room temperature. The uniaxial compressive behavior of mortar specimens for each mix proportion were tested according to JGT/T70-2009 [10]; the tests were conducted at 0.0025mm/s. The loading setup was a YAW-3000 microcomputer controlled electro-hydraulic servo tester.

\section{RESULTS AND DISCUSSION}

\subsection{Visual Observations}

During the process of heating, no explosive spalling was seen for all the mortars. It may indicate that recycled mortar has a good resistance against explosive spalling. So it may behave well when exposed to fire. No crack was observed for recycled mortars after exposure to $200^{\circ} \mathrm{C}$. When the temperature was at $400^{\circ} \mathrm{C}$, there were a few hairline cracks on the surfaces of the recycled mortars; at $600^{\circ} \mathrm{C}$, most cracks crossed the cross-section of recycled mortars.

After exposure to elevated temperature, the heated recycled mortars had different colors. When the temperature was below $200^{\circ} \mathrm{C}$, the surface of recycled mortars was gray; at $400^{\circ} \mathrm{C}$ and $600^{\circ} \mathrm{C}$, it was turned to light red and red, respectively. And it seems that no obvious relation between the color change and the recycled mortars replacement percentage. It may be attributed to the changes in chemical of recycled mortars after exposure to elevated temperature.

\subsection{Mass Loss}

The mass of each mortar specimen was measured before and after the exposure to elevated temperature, and the percentage mass loss (i.e. ratio of mass loss to mass of mortar at room temperature) is shown in Fig. (2). The Fig. (2) shows that mass loss increased gradually with the increase in exposure temperature and that mass loss was affected by the recycled mortars replacement percentage. With the same elevated temperature, the higher the recycled mortars replacement percentage, the bigger the mass loss. The mass loss was obvious when the exposure temperature increased from $20^{\circ} \mathrm{C}$ to $200^{\circ} \mathrm{C}$, due to the evaporation of abundant free water and capillary water. Up to $400^{\circ} \mathrm{C}$, the mass loss was not affected significantly. Fig. (2) shows that the mass loss of recycled mortars is larger than that of traditional mortars because recycled mortars contain more evaporable water than the traditional mortars due to the larger water absorption of the former than the latter.

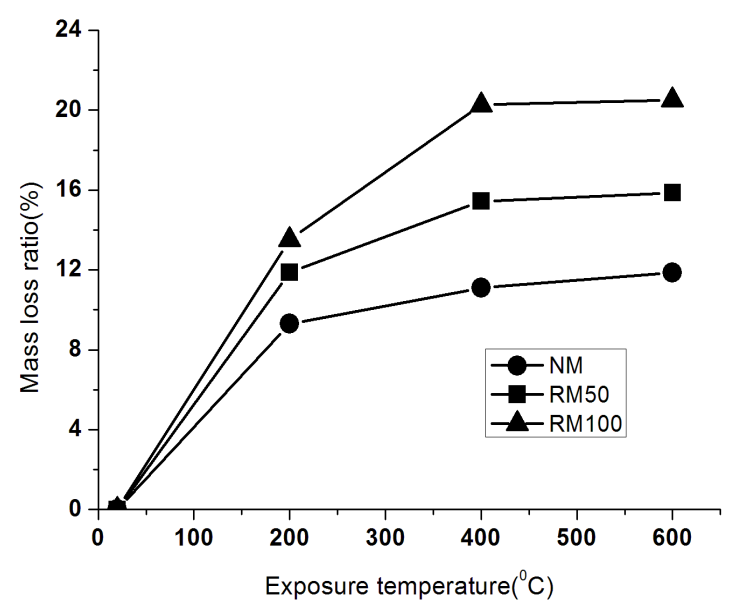

Fig. (2). Effect of elevated temperature on mass loss of mortars. 


\subsection{Compressive Strength}

Table 4 shows the residual compressive strengths of all mortars. And the variation of the residual compressive strengths with temperature is shown in Fig. (3) for recycled mortars. It is shown that the compressive strength of recycled mortars declines significantly as the temperature rises.

Table 4. Compressive strength and elastic modulus.

\begin{tabular}{|c|c|c|c|c|c|c|c|c|}
\hline \multirow{2}{*}{ Mix } & \multicolumn{4}{|c|}{ Compressive strength (MPa) } & \multicolumn{4}{c|}{ Elastic modulus (GPa) } \\
\cline { 2 - 10 } & $\mathbf{2 0}^{\circ} \mathbf{C}$ & $\mathbf{2 0 0}^{\circ} \mathbf{C}$ & $\mathbf{4 0 0}^{\circ} \mathbf{C}$ & $\mathbf{6 0 0}^{\circ} \mathbf{C}$ & $\mathbf{2 0}^{\circ} \mathbf{C}$ & $\mathbf{2 0 0}^{\circ} \mathbf{C}$ & $\mathbf{4 0 0}^{\circ} \mathbf{C}$ & $\mathbf{6 0 0}^{\circ} \mathbf{C}$ \\
\hline NM & 13.6 & 10.9 & 7.5 & 4.6 & 18.2 & 11.5 & 6.1 & 2.4 \\
\hline RM50 & 11.9 & 9.6 & 6.5 & 4.2 & 13.6 & 8.6 & 4.5 & 1.8 \\
\hline RM100 & 10.5 & 8.1 & 5.7 & 3.4 & 11.7 & 7.4 & 3.9 & 1.5 \\
\hline
\end{tabular}

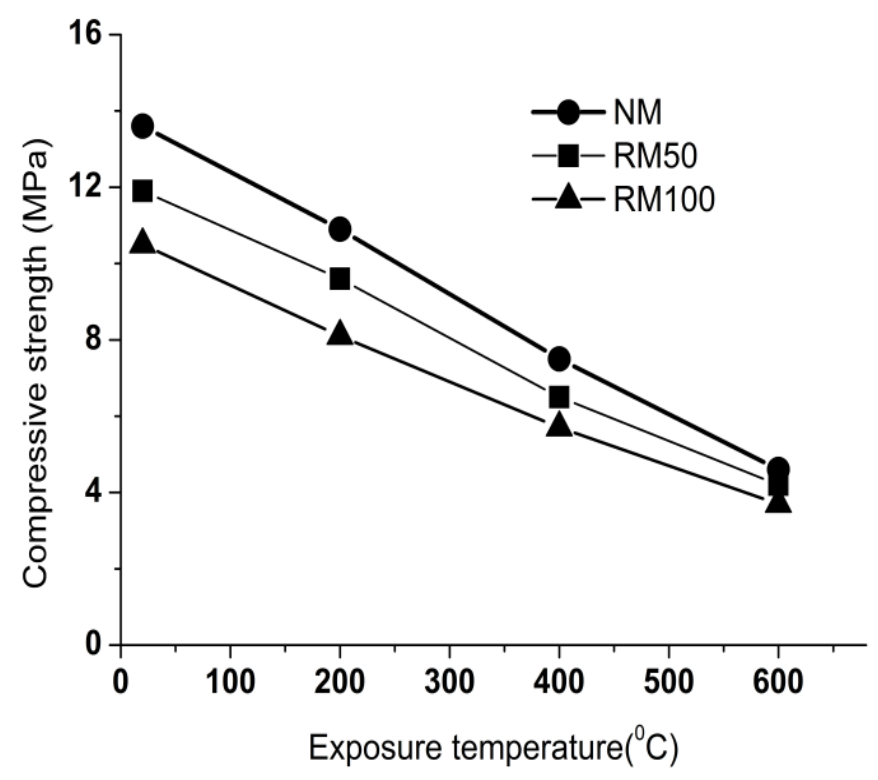

Fig. (3). Effect of elevated temperature on compressive strength of mortars.

The compressive strength at $200^{\circ} \mathrm{C}$ was $80.7 \%$ and $77.1 \%$, of the original compressive strength (at $20^{\circ} \mathrm{C}$ ) for RM50, RM100, respectively; at the same temperature for NM that was $80.1 \%$. The slight decrease in mortars strength in the temperature range from 20 to $200^{\circ} \mathrm{C}$ is attributed to the softening of the cement gel or attenuating the surface forces between gel particles. When the temperature range from 200 to $400^{\circ} \mathrm{C}$, the compressive strength of mortars dropped rapidly. At $400^{\circ} \mathrm{C}$, the compressive strength for all mortars was about $55 \%$ of that at $20^{\circ} \mathrm{C}$. Above $400^{\circ} \mathrm{C}$, the mortars had a larger compressive strength loss. The reason is that the dehydration of the cement paste results in gradual deterioration of the mortar microstructure. With further increase in temperature up to $800^{\circ} \mathrm{C}$, the residual compressive strength of NM, RM50, RM100 was 33.8\%, 35.2\%, 32.3\%, respectively. The recycled sand content has certain effect on compressive strength of the mortars. At the same temperature, the compressive strength of recycled mortars declines with the increase of the recycled sand content.

\subsection{Elastic Modulus}

Fig. (4) shows the effect of elevated temperature on elastic modulus of recycled mortars. As it can be seen from Fig. (4), for all mortars, the elastic modulus decreased with the increase in temperature, and the decrease is much quicker than the decrease in compressive strength. The reason why elastic modulus of mortars after exposure temperature is decreased may be debonding between aggregate and hardened cement paste, thermal degradation of aggregate. At $200^{\circ} \mathrm{C}$, the residual elastic modulus of all mortars was about $63.2 \%$. For RM100 specimens, it was further reduced to $33.3 \%$ and $12.8 \%$ after exposure to $400^{\circ} \mathrm{C}$ and $600^{\circ} \mathrm{C}$, respectively. Above all, the losses in elastic modulus of recycled mortars were larger than the losses in compressive strength for the same temperature. 


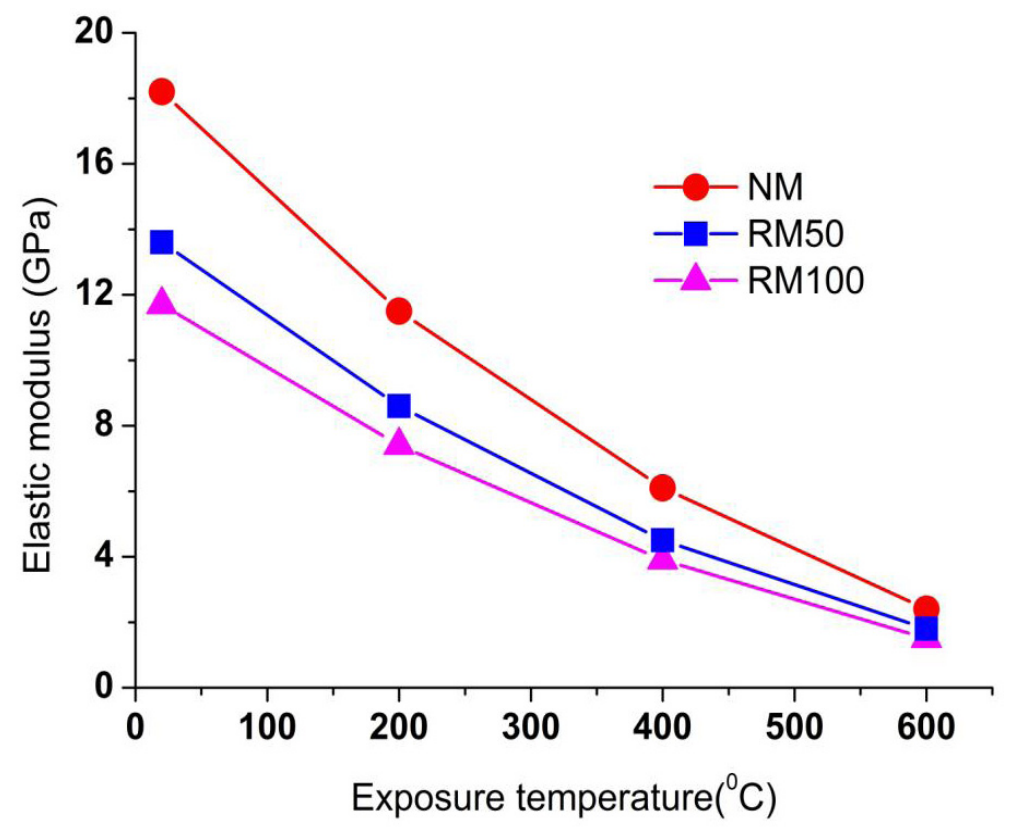

Fig. (4). Effect of elevated temperature on elastic modulus of mortars.

\subsection{Failure Mode}

Fig. (5) shows the failure modes of recycled mortars after elevated temperature. With the same elevated temperature, the failure process and modes of recycled mortars (specimens NM, RM50, RM100) were similar. When the load on the mortars was close to the peak load, the first crack appeared in the mortars while the cracking sound could be heard. After the peak load, the crack propagated along the oblique direction of recycled mortars. The load decreased quickly, and accordingly the failure process was rapid. Then the specimen was broken with splitting mode. As can be seen from Fig. (4), the angle of failure plane of recycled mortars after elevated temperature was different. The higher the elevated temperature was, the bigger the angle of failure plane.

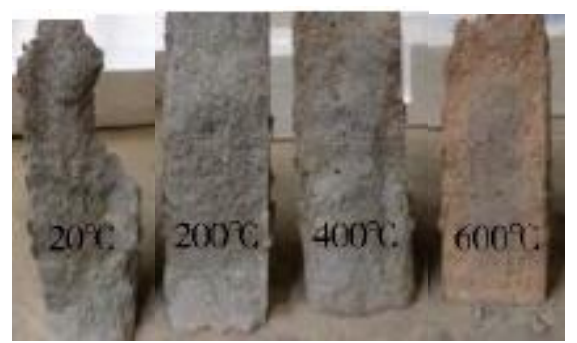

(a) Failure mode of NM after elevated temperature

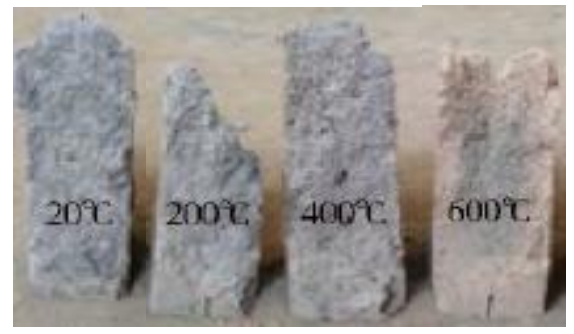

(b) Failure mode of RM100 after elevated temperature

Fig. (5). Failure mode of mortars after elevated temperature.

\section{CONCLUSION}

1. After exposure to elevated temperature, the heated recycled mortars had different colors. No obvious relation 
between the color change and the recycled mortars replacement percentage.

2. Mass loss of recycled mortars increased gradually with the increase of exposure temperature and that mass loss was affected by the recycled mortars replacement percentage. With the same elevated temperature, the higher the recycled mortars replacement percentage was, the bigger the mass loss.

3. Compressive strength of recycled mortars declines significantly as the temperature rises. The recycled sand content has certain effect on compressive strength of the mortars. At the same temperature, the compressive strength of recycled mortars declines with the increase of the recycled sand content.

4. The elastic modulus of recycled mortars decreased with the increase in temperature, and the decrease is much quicker than the decrease in compressive strength because the elastic modulus is more sentive to high temperature.

\section{CONFLICT OF INTEREST}

The authors confirm that this article content has no conflict of interest.

\section{ACKNOWLEDGEMENTS}

This work was supported by the Chinese National Natural Science Foundation (No. 51368001), the Natural Science Foundation of Jiangxi Province (20142BAB216002), the Technology Support Project of Jiangxi Province (20151BBG70012), the Open Project Program of Jiangxi Engineering Research Center of Process and Equipment for New Energy, East China Institute of Technology (No. JXNE-2014-08) and the Opening Project of Guangxi Key Laboratory of Disaster Prevention and Structural Safety (No. 2013ZDK01), which are gratefully acknowledged.

\section{REFERENCES}

[1] A.K. Padmini, K. Ramamurthy, and M.S. Mathews, "Influence of parent concrete on the properties of recycled aggregate concret", Construct. Build. Mater., vol. 23, no. 2, pp. 829-836, 2009.

[http://dx.doi.org/10.1016/j.conbuildmat.2008.03.006]

[2] J.M. Khatib, "Properties of concrete incorporating fine recycled aggregate", Cement Concr. Res., vol. 35, no. 4, pp. 763-769, 2005. [http://dx.doi.org/10.1016/j.cemconres.2004.06.017]

[3] R. Zaharieva, F. Buyle-Bodin, F. Skoczylas, and E. Wirquin, "Assessment on the surface permeation properties of recycled aggregate concrete", Cement Concr. Compos., vol. 25, no. 2, pp. 223-232, 2003.

[http://dx.doi.org/10.1016/S0958-9465(02)00010-0]

[4] T.Y. Tu, Y.Y. Chen, and C.L. Hwang, "Properties of HPC with recycled aggregates", Cement Concr. Res., vol. 36, no. 5, pp. 943-950, 2006. [http://dx.doi.org/10.1016/j.cemconres.2005.11.022]

[5] F.B. Bodin, and R.H. Zaharieva, "Influence of industrially produced recycled aggregates on flow properties of concrete", Mater. Struct., vol. 35 , no. 8, pp. 504-509, 2002.

[http://dx.doi.org/10.1007/BF02483138]

[6] Z.F. Zhao, S. Remond, D. Damidot, and W.Y. Xu, "Influence of fine recycled concrete aggregates on the properties of mortars", Construct. Build. Mater., vol. 81, pp. 179-186, 2015.

[http://dx.doi.org/10.1016/j.conbuildmat.2015.02.037]

[7] E.F. Ledesma, J.R. Jiménez, J.M. Fernández, A.P. Galvín, F. Agrela, and A. Barbudo, "Properties of masonry mortars manufactured with fine recycled concrete aggregates", Construct. Build. Mater., vol. 71, pp. 289-298, 2014. [http://dx.doi.org/10.1016/j.conbuildmat.2014.08.080]

[8] Sand for Construction (GBT14684-2011), Chinese Building Construction Publishing Press: Beijing, 2011. (in Chinese)

[9] Common Portland Cement (GB175-2007), Chinese Building Construction Publishing Press: Beijing, 2007. (in Chinese)

[10] Standard for Test Method of Basic Properties of Construction Moatar in China (JGT/T70-2009), Chinese Building Construction Publishing Press: Beijing, 2009. (in Chinese)

(C) Liang et al.; Licensee Bentham Open

This is an open access article licensed under the terms of the Creative Commons Attribution-Non-Commercial 4.0 International Public License (CC BY-NC 4.0) (https://creativecommons.org/licenses/by-nc/4.0/legalcode), which permits unrestricted, non-commercial use, distribution and reproduction in any medium, provided the work is properly cited. 